\title{
PENERAPAN METODE TILAWATI PADA MATA PELAJARAN BACA TULIS AL-QUR'AN DI SDIT MUKHLISIIN KABUPTEN GOWA
}

\author{
Hartono \\ PPs UIN Alauddin Makassar \\ Email: hartonopai1uinalauddinmakassar@gmail.com
}

\begin{abstract}
This study discusses the Application of the Tilawati Method to the Qur'anic Reading Subjects at SDIT Mukhlisiin. The aim is to find out the form of implementation of the Tilawati Method in the Koran reading and writing subjects in SDIT Mukhlisiin, the supporting factors and obstacles to the implementation of the tilawati method in the Koran reading and writing in SDIT Mukhlisiin as well as solutions to the inhibiting factors in implementation the application of the tilawati method to the Qur'anic literacy subjects at SDIT Mukhlisiin. This type of research is classified as qualitative with a research approach that is a scientific approach and a scientific study approach. The scientific approach includes the sociological approach and the scientific study approach which includes interdisciplinary, namely pedagogical approaches and psychological approaches. The results of this study indicate that the Implementation of the Tilawati Method in the Qur'anic literacy subjects at SDIT Mukhlisiin runs well, but some of the Qur'anic literate teachers have not been maximal in applying the tilawah method to the reading and writing subjects 's at SDIT Mukhlisiin because the time given is still minimal. The application of the tilawati method to the Koran reading and writing in SDIT Mukhlisiin is expected to contribute to the teachers who come in direct contact with the students, especially the Koran literate teachers in order to maximize their duties as professional educators, and develop themselves in applying the recitations method.
\end{abstract}

Keywords: Method, recitations, recite the Qur'an

\section{PENDAHULUAN}

\section{A. Latar Belakang}

$\mathrm{P}$ endidikan merupakan suatu investasi terbesar dalam merancang pola kehidupan manusia ke depan. Pendidikan sesungguhnya selalu bersangkut paut dengan masa depan, sebab pendidikan pada dasarnya adalah usaha sadar untuk menyiapkan peserta didik melalui kegiatan bimbingan, pengajaran, dan latihan bagi perannya di masa depan. Pendidikan adalah wahana untuk mengembangkan potensi dan aktualisasi pada diri manusia, yaitu potensi kebaikan dan mengerdilkan potensi kejahatan. ${ }^{1}$

Dengan modal pendidikan, manusia memiliki tiga keuntungan. Pertama, pendidikan sebagai upaya yang berorientasi pada pembentukan sosok manusia yang

\footnotetext{
${ }^{1}$ Umar Tirta Harja \& L. La Sulo, Pengantar Pendidikan (Jakarta: PT Rineka Cipta, 2005), h. 303.
} 
memiliki potensi secara intelektual melalui proses pembelajaran. Kedua, pendidikan merupakan pembentukan masyarakat yang berkarakter dan beretika melalui nilai-nilai yang terkandung di dalamnya. Ketiga, pendidikan merupakan salah satu jaminan untuk memperoleh kehidupan yang lebih baik. Melalui pemahaman tersebut, pendidikan secra otomatis menempati posisi yang sangat sentral dalam membangun kehidupan manusia ke depan yang berkualitas dan seimbang.

Pandangan tersebut menunjukkan bahwa pendidikan merupakan kebutuhan manusia sepanjang perjalanan hidup mereka. Pendidikan selalu dibutuhkan manusia sampai kapan dan dimanapun ia berada. Tanpa adanya pendidikan, manusia akan sulit mengembangakan potensi yang dimilikinya, bahkan justru sebaliknya manusia akan mengalami keterbelakangan dan kejumudan.

Pelaksanaan kegiatan pendidikan dalam suatu lembaga pendidikan sudah pasti memerlukan peserta didik, kemudian peserta didik merupakan orang yang belum dewasa yang memerlukan bimbingan dan membantu mengembangkan potensi yang dimiliki oleh setiap peserta didik. ${ }^{2}$ Pengembangan potensi peserta didik tidak hanya berorientasi pada ranah kognitif saja, tetapi juga perkembangan emosi sehingga dalam perkembangan individu tidak mengalami ketimpangan yang menyebabkan pada tindakan moral yang dilakukan peserta didik. Dengan demikian, dapat dipahami bahwa, proses pendidikan yang berlangsung pada peserta didik merupakan rangkaian usaha membimbing, dan mengarahkan potensi dasar dan kemampuan belajar yang dimilikinya, sehingga pada gilirannya melahirkan perubahan di dalam diri dan kehidupannya sebagai makhluk individu dan sosial serta hubungannya dengan alam sekitar tempat dimana ia hidup.

Pengajaran berlangsung sebagai proses saling memengaruhi antara guru dan peserta didik. Di antara keduanya terdapat hubungan atau interaksi. Guru mengajar di satu pihak dan peserta didik belajar di lain pihak. Keduanya menunjukkan aktivitas yang seimbang, hanya berbeda peranan saja. Keterpaduan proses belajar peserta didik dengan proses mengajar guru sehingga terjadi interaksi belajar mengajar (terjadi proses pengajaran) tidak datang begitu saja dan tidak dapat tumbuh tanpa pengaturan dan perencanaan yang seksama. Pengaturan sangat diperlukan terutama dalam menentukan komponen dan variabel yang harus ada dalam proses pengajaran tersebut. Perencanaan dimaksudkan merumuskan dan menetapkan interrelasi sejumlah komponen dan variabel sehingga memungkinkan terselenggaranya pengajaran yang efektif. ${ }^{3}$

\section{B. Tinjauan Pustaka}

Sebelum peneliti menguraikan secara umum tentang penegertian metode tilawati, terlebih dahulu peneliti menguraikan pengertian metode. Metode berasal dari dua kata, yaitu meta dan hodos. Meta berarti melalui, sedangkan hodos berarti jalan atau cara. Jadi,

${ }^{2}$ Sama'un Bakry, Menggagas Konsep Ilmu Pendidikan Islam (Bandung: Pustaka Bani Quraisy, 2005), h. 66.

${ }^{3}$ Nana Sudjana, Dasar-dasar Proses Belajar Mengajar(Bandung:Sinar Baru Algensindo, 2004), h. 29 
metode menurut bahasa adalah jalan atau cara yang harus dilalui untuk mencapai suatu tujuan. ${ }^{4}$ Sedangkan tilāwati(تلاوتي) berasal dari dua kata arab yaitu kata tilāwah (تلاوة) dan ya mutakallim (ي). Kata tilāwah berakar dari kata talä-yatlī-tilāwatan berarti bacaan. Sedangkan kata "ي" (yä' mutakallim) adalah domïrun muttasil yang memiliki arti saya. Jadi, tilawati bararti bacaan saya. metode tilwati adalah suatu metode atau cara belajar membaca al-Qur'an dengan ciri khas tersendiri. Adapun ciri khas yang dimaksudkan adalah disampaikan secara praktis, menggunakan lagu rost, menggunakan pendekatan klasikal dengan menggunakan peraga dan menggunakan pendekatan individual dengan teknik baca simak dengan menggunakan buku tilawati.

1. Target Pembelajaran Metode Tilawati

Untuk memperoleh hasil yang maksimal dalam kegiatan pelaksanaan pembelajaran pada penerapan metode tilawati, maka target yang ditetapkan adalah target kualitas dan target waktu. Target kualitas yang dimaksud di sini adalah tartil membaca al-Qur'an yang meliputi: Pertama, fașāhạ yaitu kesempurnaan dalam mengucapkan huruf dan kesempurnaan dalam membaca ayat dan kalimat. Kedua, tajwid yaitu menguasai makhraj huruf, sifat huruf, hukum-hukum huruf dan hukum panjang dan pendek bacaan. Ketiga, yanggharib dan yang musykil. Gharib adalah bacaan-bacaan dalam al-Qur'an yang cara membacanya tidak sesuai dengan kaidah ilmu tajwid secara umum. Sedangkan musykil adalah bacaan dalam al-Qur'an yang mengandung kesulitan dalam membacanya sehingga harus berhati hati. Keempat, suara dan lagu yaitu suaranya jelas dan lantang dalam membaca al-Qur'an dan lagunya harus menguasai lagu rost tiga nada yaitu nada datar, naik dan turun. Target waktu yang dimaksudkan di sini adalah peserta didik dapat menuntaskan seluruh materi dengan waktu yang di tempuh selama tiga tahun dalam dua jenjang atau tingkatan, yaitu tingkat dasar dengan menggunakan jilid satu sampai dengan jilid lima dan tingkat lanjutan dengan tadarrus al-Qur'an 30 juz. Waktu yang dibutuhkan tingkat dasar dalam proses pembelajaran metode tilawati adalah 15 bulan dengan ketentuan 5 kali tatap muka dalam seminggu dan 75 menit setiap tatp muka. Adapun rincian waktu selama 75 menit adalah 5 menit materi do'a pembuka dengan pendekatan teknik klasikal dan menggunakan lagu rost, 15 menit materi dengan menggunakan peraga tilawati dengan teknik klasikal dan menggunakan lagu rost, 30 menit materi dengan menggunakan buku tilawati dengan teknik baca simak dan menggunakan lagu rost, 20 menit materi penunjang dengan menggunakan teknik klasikal dan lagu rost dan 5 menit materi penutup dengan teknik klasikal dan menggunakan lagu rost.

2. Materi Tilawati disetiap Jilidnya adapun materi tilawati disetiap jilidnya yang kami ajarkan adalah sebagai berikut:

a. Tilawati jilid 1: mengenalkan huruf-huruf hijaiyah berharakat fathah tidak

${ }^{4}$ Arifin, Ilmu Pendidikan Islam (Suatu Tinjauan Teoritis dan Praktis Berdasarkan Pendekatan Interdisipliner) (Cet. IV; Jakarta: Bumi Aksara, 2000), h. 61.

${ }^{5}$ Husain Al-Habasyi, Kamus al-KautsarArab Indonesia Lengkap Ed. III, (Bengil: Yayasan Pesantren Islam, 1985), h. 79. 
bersambung dan bersambung, secara langsung tanpa dieja dan di dalam kotak bagian bawah, mengenalkan huruf hijaiyah asli tanpa harakat dan angka Arab. Pada halaman-halaman belakang mulai diperkenalkannya huruf-huruf sambung yang terdiri dari dua huruf dan tiga huruf.

b. Tilawati jilid 2: mengenalkan kalimat berharakat fathah, kasrah, dhammah dan tanwin. Pada halaman 18 mengenalkan macam-macam "Ta" dan pada halaman 20 mengenalkan bacaan panjang satu alif serta mengenalkan bacaan mad thobi'i. Sedangkan pada kotak bagian bawah mengenalkan nama-nama harakat.

c. Tilawati jilid 3: mengenalkan huruf lam berharakat sukun, alif lam qomaririyah supaya ditekan dalam membacanya, mengenalkan makhroj mim, sin, syin, ra', hamzah, ta, 'ain, fa, dal, dho, tsa, kha, ghoin, za, shod, kaf, ha', dhol sukun. Pada halaman 15 dan 16 diperkenalkan bacaan fathah yang diikuti wawu dan ya' sukun.

d. Tilawati jilid 4: mengenalkan huruf-huruf yang berharakat tasydid, bacaan mad wajib dan mad jaiz, bacaan nun dan mim tasydid (ghunnah). Pada halaman 12 mulai mengajarkan cara membunyikan akhir kalimat ketika waqaf, pada halaman 14 mengenalkan lafdzul jalalah setelah kasroh dibaca tipis dan apabila sesudah fathah dan dhommah dibaca tebal, pada halaman 16 mengenalkan bacaan alif lam syamsiyah, pada halaman 19 mengenalkan bacaan ikhfa' hakiki setiap nun sukun harus dibaca samar dan dibaca dengung selama satu setengah alif. Pada halaman 20 mengenalkan huruf muqottho'ah pada kotak bagian bawah dan pada halaman 23 mengenalkan wawu yang tidak ada sukunnya. Sedangkan pada halamn 33 megenalkan bacaan idghom bigunnah.

e. Tilawati jilid 5: mengenalkan bacaan idghom bigunnah apabila nun sukun berharakat sukun atau tanwin berhadapan dengan huruf ya' maka suara nun sukun atau tanwin masuk pada huruf ya dibaca dengung selama satu setengah alif, mengenalkan bacaan qolqolah, mengenalkan bacaan iqlab, mengenalkan bacaan idghom mimi dan ikhfa syafawi, mengenalkan bacaan idghom bilagunnah, pada halaman 19 mengenalkan cara membaca lam sukun apabila bertemu dengan ra' maka suara lam sukun masuk pada huruf ra', mengenalkan bacaan idzhar halqi, pada halaman 41 mengenalkan bacaan mad lazim mutsaqqol kalimi dan mad lazim mukhoffaf harfi dan pada halaman 42 mengenalkan tanda-tanda waqaf.

f. Tilawati jilid 6: pokok bahasannya berupa surat-surat pendek mulai surat ke 93(Adduha) sampai dengan surat terakhir 114 (Annas), ayat-ayat pilihan seperti ayat kursy al-Baqarah ayat 255 serta pada halaman 22 sampai halaman 44 mengenalkan musykilat dan ghorib (bacaan-bacaan asing yang tidak cocok dengan tulisannya).

\section{Tujuan Penilitian}

Salah satu masalah penting yang dihadapi guru mata pelajaran baca tulis al-Qur'an, khususnya di SDIT Mukhlisiin adalah mengatasi ketidak tertiban peserta didik selama proses belajar mengajar dan mengatasi ketidaklancaran mengaji. Ketidaktertiban peserta didik selama proses belajar mengajar dan ketidak lancaran mengaji berdampak pada 
mutu bacaan peserta didik makin merosot dan waktu belajarnya semakin lama bahkan tidak sedikit peserta didik drop out sebelum tartil dan khatam baca al-Qur'an.

Seiring perkembangn zaman maka banyak metode-metode yang diciptakan untuk menunjang keberhasilan peserta didik dalam membaca al-Qur'an dengan ciri khas tertentu demi memcapai keberhasilan dalam pembelajaran. Salah satu metode yang telah berkembang pada abad ini, yaitu metode Tilawati. Metode Tilawati merupakan metode belajar membaca al-Qur'an dengan ciri tertentu, di antara cirinya adalah menggunakan lagu rost dengan pendekatan yang seimbang antara pembiasaan melalui klasikal dan kebenaran membaca melalui individual dengan teknik baca simak. ${ }^{6}$ Sehingga dalam pembelajaran peserta didik dapat tuntas dan khatam dalam membaca al-Qur'an dengan menggunakan metode tilawati.

Fanomena tersebutlah yang memotivasi penulis untuk menganalisis tentang penerapan metode tilawati pada mata pelajaran baca tulis al-Qur'an di SDIT Mukhlisiin. SDIT Mukhlisiin Sekolah Dasar Islam Terpadu Mukhlisiin Kab. Gowa merupakan salah satu dari beberapa SDIT yang berada di Gowa yang menerapkan metode tilawati sebagai metode dalam pembelajaran membaca al-Qur'an dan pembiasaan lainnya yang bertujuan untuk menyiapkan anak didiknya agar menjadi generasi muda yang Qur'ani.

\section{PENERAPAN METODE TILAWATI PADA MATA PELAJARAN BACA TULIS AL-QUR'AN DI SDIT MUKHLISIIN}

\section{A. Gambaran Sekolah Dasar Islam Terpadu Mukhlisiin}

SDIT mukhlisiin adalah sekolah yang menerapkan metode tilawati pada mata pelajaran baca tulis al-Qur'an. SDIT Mukhlisiin didirikan pada tahun 2015, berdasarkan NPSN: 69906413. Sejak berdirinya SDIT Mukhlisiin belum pernah mengalami pergantian kepala sekolah. Eksistensi SDIT Mukhlisiin berada di jalan Jambu No. 07 Tombolo, Desa Je'netallasa, Kec. Pallangga, Kab. Gowa. Adapun status tanah dan bangunan adalah kepemilikan swasta, luas tanah kurang lebih $3500 \mathrm{~m}^{2}$.

\section{B. Bentuk Pelaksanaan Penerapan Metode Tilawati Pada Mata Pelajaran Baca Tulis al-Qur'an di SDIT Mukhlisiin}

Metode tilawati adalah salah satu cara belajar membaca al-Qur'an yang diterapkan di Sekolah Dasar Islam Terpadu Mukhlisiin. Metode ini diajarkan oleh guru yang berkompeten, yang telah mengikuti pelatihan khusus. Adapun bentuk-bentuk pelaksanaan penerapan metode tilawati pada mata pelajaran baca tulis al-Qur'an di SDIT Mukhlisiin berdasarkan observasi penelitiyang diterapkan oleh guru baca tulis al-Qur'an itu sendiri adalah guru menyiapkan alat peraga, mengatur peserta didik, memulai proses pembelajaran dengan membaca do'a, memberikan arahan kepada peserta didik untuk memperhatikan alat peraga, memulai pembelajaran dengan teknik I, II dan III, guru melanjutkan bacaan dengan menggunakan buku tilawati, guru menginstruksikan kepada

\footnotetext{
${ }^{6}$ Abdurrahim Hasan dan Muhammad Arif dkk, Strategi Pembelajaran al-Qur'an Metode Tilawati (Surabaya:Pesantren al-Qur'an Nurul Falah, 2010), h. 4.
} 
peserta didik untuk membaca materi secara bergantian, guru memerintahkan peserta didik untuk menulis lembaran materi yang telah ditentukan dan selanjutnya melakukan doa penutup secara bersama antara guru dan peserta didik.

\section{Faktor-Faktor yang Mendukung dan Menghambat dalam Penerapan Metode Tilawati Pada Mata Pelajaran Baca Tulis al-Qur'an di SDIT Mukhlisiin}

1. Faktor yang Mendukung Penerapan Metode Tilawati Pada Mata Pelajaran Baca Tulis al-Qur'an di SDIT Mukhlisiin

a. Semangat Peserta Didik

Peseta didik adalah seorang individu yang mengalami fase perkembangan atau pertumbuhan dari segi fisik dan mental maupun fikiran. Salah satu faktor keberhasilan dalam proses pembelajaran adalah peserata didik harus memiliki motivasi atau semangat dalam belajar. Motivasi atau semangat dalam jiwa peserta didik merupakan suatu dorongan untuk belajar tanpa ada paksaa.

Hasil wawancara dengan Ahmadin selaku guru baca tulis al-Qur'an yang mengatakan bahwa dalam proses pelaksanaan pembelajaran kami selaku guru baca tulis al-Qur'an di SDIT Mukhlisiin juga memiliki semangat tersendiri setelah melihat peserta didik begitu bersemangat dan antusias dalam proses pembelajaran baca tulis al-Qur'an.

Jadi, guru baca tulis al-Qur'an memiliki semangat yang membara setelah melihat peserta didiknya begitu bersemangat dalam proses pembelajaran khususnya pada mata pelajaran baca tulis al-Qur'an sehingga menciptakan pembelajaran aktif.

b. Kompetensi dan Kualifikasi Akademik Guru

Profesi guru merupakan jabatan fungsional yang menuntut adanya profesionalisme, sehingga profesi tersebut harus dikerjakan oleh guru yang memiliki kompetensi dan kualifikasi akademik. Kompetensi dan kualifikasi akademik seorang guru menjadi salah satu tolok ukur untuk menilai keberhasilan guru dalam mendidik dan menginternalisasikan nilai-nilai kebaikan dalam diri peserta didik. Sebagaimana yang diungkapkan oleh Andi Kusuma selaku kepala sekolah menyatakan bahwa faktor internal yang mendukung guru baca tulis al-Qur'an dalam menerapkan metode tilawati pada mata pelajaran baca tulis al-Qur'an adalah memiliki kompetensi dan kualifikasi akademik. Kualifikasi akademik dimilki oleh guru baca tulis al-Qur'an di SDIT Mukhlisiin tersebut menurutnya sudah sesuai dengan standarisasi guru profesional yaitu minimal sarjana dan berkompeten.

\section{c. Alat Peraga dan Buku Tilawati}

Faktor yang mendukung pelaksanaan penerapan metode tilawati ini pada pada mata pelajaran baca tulis al-Qur'an di SDIT Mukhlisiin adalah adanya alat peraga dan buku tilawati yang disediakan oleh pihak SDIT Mukhlisiin. Demi menciptakan pembelajaran yang aktif dan efektif pihak sekolah berusaha memenuhi apa-apa yang dibutuhkan di SDIT Mukhlisiin khususnya pada mata pelajaran baca tulis al-Qur'an. 


\section{d. Pelatihan Metode Tilawati}

Pihak sekolah itu sendiri sangat mendukung metode tilawati yang diterapkan di SDIT Mukhlisiin pada pelaksanaan mata pelajaran baca tulis al-Qur'an. Bukti kesungguhan pihak sekolah dengan pelaksanaan penerapan metode tilawati pada mata pelajaran baca tulis al-Qur'an sehingga ia mengadakan pelatihan kepada seluruh elemen guru dan terkhusus kepada guru baca tulis al-Qur'an itu sendiri.

2. Faktor yang Menghambat Penerapan Metode Tilawati Pada Mata Pelajaran Baca Tulis al-Qur'an di SDIT Mukhlisiin

a. Kurangnya Alokasi Waktu

Sedikitnya alokasi waktu pembelajaran dalam kelas adalah menjadi bagian dari kendala atau penghambat bagi guru baca tulis al-Qur'an dalam melaksanakan penerapkan metode tilawati pada mata pelajaran baca tulis al-Qur'an di SDIT Mukhlisiin, sehingga tidak memungkinkan bagi guru baca tulis al-Qur'an untuk menerapkan metode tersebut secara maksimal akan tetapi guru baca tulis al-Qur'an berusaha untuk menciptakan pembelajaran yang aktif.

Sebagaimana diungkapkan oleh Ahmadin bahwa salah satu penghambat kami dalam melaksanakan penerapkan metode tilawati di sekolah ini adalah kurangnya alokasi waktu untuk menerapkan metode tilawti kepada peserta didik. Adapun waktu jam pelajaran yang diberikan oleh pihak sekolah adalah 60 menit dalam satu kali pertemuan, dan pertemuan hanya satu kali dalam sepekan.

b. KeterlambatanAlat Peraga dan Buku Tilawati

Keterlambatan kedatangan alat peraga dan buku tilawati sehingga menghambat proses pelaksanaan pembelajaran pada mata pelajaran baca tulis al-Qur'an terkhusus dalam pelaksanaan penerapkan metode tilawat.

c. Tidak Sering Diadakan Pelatiahan

Pihak sekolah memang mengadakan pelatihan metode tilawati kepada seluruh elemen guru terkhusus pada guru baca tulis al-Qur'an itu sendiri akan tetapi pelatihan tersebut tidak sering diadakan. Pihak sekolah hanya menyelenggarakan pelatihan satu kali dalam satu semester. Sebagaiman hasil wawancara dari salah satu guru baca tulis alQur'an yang mengatakan bahwa pihak sekolah memang mengadakan pelatihan metode tilawati tetapi pelatihan tersebut tidak sering diadakan. Dan kami selaku guru baca tulis al-Qur'an menginginkan pelatihan tersebut diadakan satu kali dalam satu bulan atau satu kali dalam dua bulan.

\section{Solusi Mengatasi Faktor Penghambat dalam Penerapan Metode Tilawati Pada Mata Pelajaran Baca Tulis al-Qur'an di SDIT Mukhlisiin}

1. Memberikan Materi Secara Singkat

Melihat alokasi waktu yang diberikan oleh pihak sekolah sangat kurang, maka kami selaku guru baca tulis al-Qur'an harus pandai-pandai merinci atau mempersingkat materi yang akan kami berikan kepada peserta didik sehingga bisa selesai sesui dengan waktu 
yang diberikan oleh pihak sekolah. Seperti mengurangi waktu berdo'a pembuka dan penutup dari lima menit menjadi dua sampai tiga menit saja, mengurangi waktu materi penunjang dari dua puluh menit menjadi sepuluh menit.

\section{Mengulangi Bacaan yang ada Pada Alat Peraga Sebelumnya}

Dengan keterlambatan kedatangan alat peraga dan buku tilawati sehingga proses pelaksanaan pembelajaranterhambat. Adapun yang dilakukan oleh guru baca tulis alQur'an dalam mengatasi keterlmbatan alat peraga dan buku tilawati adalah dengan cara mengulangi bacaan yang ada pada alat peraga sebelumnya sambil menunggu alat peraga dan dan buku tilawati yang baru. Dengan mengulangi materi yang telah dilalui dengan alat peraga sebelumnya atau dengan alat peraga yang tersedia sehingga membuat peserta didik tidak melupakan pelajaran sebelumnya.

\section{Mengadakan Latihan Bersama}

Sebagaimana telah kita ketahui bersama bahwa salah satu penghambat penerapan metode tilawati adalah tidak seringnya diadakan pelatiahan. Dengan tidak seringnya diadakan pelatihan metode tilawati maka kami selaku guru baca tulis al-Qur'an mengadakan latihan bersama di akhir-akhir bulan dan kami melakukannya hanya sekali dalam satu bulan.

\section{PENUTUP}

Berdasarkan hasil penelitian yang berkaitan dengan Penerapan Metode Tilawati Pada Mata Pelajaran Baca Tulis al-Qur'an di SDIT Mukhlisiin dapat disimpulkan bahwa metode tilwati adalah suatu metode atau cara belajar membaca al-Qur'an dengan ciri khas tersendiri. Dengan metode tilawati peserta didik mampu membaca al-Qur'an dengan baik dan benar sesui dengan kaidah dan hukum tajwid serat peserta didik dapat mengikuti proses pembelajaran dengan tertib. Metode tilawati mampu menjawab kegalauan kegalaun guru baca tulis al-Qur'an, khususnya di SDIT Mukhlisiin. Walaupun guru mata pelajaran baca tulis al-Qur'an dihadapkan dengan beberapa kendala atau penghambat dalam pelaksanaan metodeti akan tetapi mereka selalu berusaha menciptakan pembelajaran yang dicita citakan, yaitu efektif dan efesien.Adapun bentuk-bentuk pelaksanaan penerapan metode tilawati pada mata pelajaran baca tulis al-Qur'an di SDIT Mukhlisiin berdasarkan observasi penelitiyang diterapkan oleh guru baca tulis al-Qur'an itu sendiri adalah guru menyiapkan alat peraga, mengatur peserta didik, memulai proses pembelajaran dengan membaca do'a, memberikan arahan kepada peserta didik untuk memperhatikan alat peraga, memulai pembelajaran dengan teknik I, II dan III, guru melanjutkan bacaan dengan menggunakan buku tilawati, guru menginstruksikan kepada peserta didik untuk membaca materi secara bergantian, guru memerintahkan peserta didik untuk menulis lembaran materi yang telah ditentukan dan selanjutnya melakukan doa penutup secara bersama-sama antara guru dan peserta didik.

Faktor-Faktor yang Mendukung dan Menghambat dalam Penerapan Metode Tilawati Pada Mata Pelajaran Baca Tulis al-Qur'an di SDIT Mukhlisiin. (a) Faktor yang 
Mendukung Penerapan Metode Tilawati Pada Mata Pelajaran Baca Tulis al-Qur'an di SDIT Mukhlisiin yaitu Semangat peserta didik, kompetensi dan kualifikasi akademik guru, alat peraga dan buku tilawati, pelatihan metode tilawati. (b) Faktor yang Menghambat Penerapan Metode Tilawati Pada Mata Pelajaran Baca Tulis al-Qur'an di SDIT Mukhlisiin yaitu kurangnya alokasi waktu, keterlambatan alat peraga dan buku tilawati, tidak sering diadakan pelatiahan.

Solusi Mengatasi Faktor Penghambat dalam Penerapan Metode Tilawati Pada Mata Pelajaran Baca Tulis al-Qur'an di SDIT Mukhlisiin yaitu memberikan materi secara singkat, mengulangi bacaan yang ada pada alat peraga sebelumnya, mengadakan latihan bersama.

\section{DAFTAR PUSTAKA}

Arif, Muhammad danAbdurrahim Hasan dkk, Strategi Pembelajaran al-Qur'an Metode Tilawati, Surabaya:Pesantren al-Qur'an Nurul Falah, 2010.

Arifin, Ilmu Pendidikan Islam (Suatu Tinjauan Teoritis dan Praktis Berdasarkan Pendekatan Interdisipliner), Cet. IV; Jakarta: Bumi Aksara, 2000.

Bakry,Sama'un, Menggagas Konsep Ilmu Pendidikan Islam, Bandung: Pustaka Bani Quraisy, 2005.

Al-Habasyi, Husain, Kamus al-KautsarArab Indonesia Lengkap Ed. III, Bengil: Yayasan Pesantren Islam, 1985.

Sudjana,Nana Dasar-dasar Proses Belajar Mengajar , Bandung:Sinar Baru Algensindo, 2004.

Sulo, L. La\& Umar Tirta Harja, Pengantar Pendidikan, Jakarta: PT Rineka Cipta, 2005. 